\title{
Incomplete contracts for bus service during the COVID-19 pandemic
}

\section{Gregório Costa Luz de Souza Lima ${ }^{1}$ \\ Gabriel Stumpf Duarte de Carvalho ${ }^{2}$ \\ Miguel Zobaran Figueiredo ${ }^{3}$}

${ }^{1}$ Universidade Federal do Rio de Janeiro / Transportation Engineering Program, Rio de Janeiro / RJ - Brazil

${ }^{2}$ Instituto Superior Técnico de Lisboa / Department of Civil Engineering, Architecture and Georesources, Lisbon - Portugal

${ }^{3}$ Fundação Getulio Vargas / Center for Regulatory and Infrastructure Studies, Rio de Janeiro / RJ - Brazil

The COVID-19 pandemic poses serious challenges for the public bus service. The fall in demand due to social distancing measures, the intensification of hygiene procedures, the acquisition of personal protective equipment, and restrictions on vehicle capacity threaten the financial viability of Brazilian public transportation. The COVID-19 pandemic may be characterized as a force majeure event, giving rise to an economic-financial balancing of public bus service contracts. However, this solution must be built by the public administration and transport companies to guarantee the interests and needs of both parties. Therefore, this article offers strategies to continue operating the service during the pandemic and to achieve economic and financial equilibrium protecting the public interest. Overcoming the uncertainties and consequences caused by the pandemic requires relationships of trust and mutual support between the private sector (operators) and government.

Keywords: COVID-19; public transport; economic and financial equilibrium; contracts.

\section{A incompletude dos contratos de ônibus nos tempos da COVID-19}

A pandemia da COVID-19 impõe sérios desafios ao setor de transporte público por ônibus. A queda da demanda em razão do isolamento social, a intensificação dos procedimentos de higienização, a aquisição de equipamentos de proteção individual e as restrições de lotação dos veículos ameaçam a viabilidade econômico-financeira do transporte coletivo brasileiro. A pandemia da COVID-19 pode ser caracterizada como um evento de força maior, ensejando reequilíbrio econômico-financeiro dos contratos de concessão de transporte público por ônibus. Entretanto, esta solução precisa ser buscada conjuntamente, pelo poder público e pelas empresas de transporte urbano, para garantir os interesses e as necessidades de ambas as partes. Este artigo sugere ações estratégicas para que o transporte coletivo continue operando durante a pandemia e os acordos de reequilíbrio econômicofinanceiro estejam alinhados com o interesse público. A superação das incertezas e consequências causadas pela pandemia exige a criação de relações de confiança e apoio mútuo entre inciativa privada (operadores) e governo. Palavras-chave: COVID-19; transporte público; reequilíbrio econômico-financeiro; contratos.

\section{La incompletitud de los contratos de autobús en tiempos de COVID-19}

La pandemia de COVID-19 impone desafíos serios para el sector de transporte público por autobús. La caída de la demanda en función de las medidas de aislamiento social, la intensificación de los procedimientos de higiene, la adquisición del equipo de protección para los trabajadores y las restricciones en cuanto al número de pasajeros por vehículo amenazan la viabilidad económica-financiera del transporte colectivo brasileño. La pandemia de COVID-19 se puede caracterizar como acontecimiento de fuerza mayor que propicie el reequilibrio económico-financiero de contratos de concesión de transporte público por autobús. Sin embargo, esta solución debe buscarse en forma conjunta, por el gobierno y las empresas de transporte, para garantizar los intereses y las necesidades de ambas partes. Este artículo sugiere acciones estratégicas para que el transporte colectivo continúe funcionando durante la pandemia y los acuerdos de reequilibrio económico-financiero se alineen con el interés público. La superación de las incertidumbres y consecuencias de la pandemia requiere la creación de relaciones de confianza y apoyo mutuo entre la iniciativa privada (operadores) y los gobiernos.

Palabras clave: COVID-19; transporte público; equilibrio económico-financiero; contratos. 


\section{INTRODUCTION}

The COVID-19 pandemic has suspended non-essential daily activities. Among the measures Brazilian states and municipalities adopted to prevent the spread of the new coronavirus is the voluntary, or mandatory, horizontal social isolation of non-essential workers. The public managers cannot misunderstand measures that limit the population's circulation with the public transportation shutdown (Lima, Schechtman, Brizon, \& Figueiredo, 2020).

Despite the small number of people commuting, stopping public transport services does not seem to be an option. In a study conducted in the 20 largest Brazilian cities, Pereira et al. (2020) estimated the following: there are more than 228 thousand people over 50 years of age who live farther than 30 minutes' walk from a public health care facility capable of admitting suspected cases; $41 \%$ of the low-income population over 50 years of age live at least $5 \mathrm{~km}$ further from health units capable of treating patients in critical condition. In the Metropolitan Region of São Paulo, 55.7\% of health-related trips are by public transportation (Metro-SP, 2019). Public transport plays an essential role for people seeking medical assistance (Lima et al., 2020; Union Internationale des Transport Publics [UITP], 2020) and cannot be shut down.

Although essential for reducing the spread of COVID-19, social isolation measures have a considerable impact on the economy, especially in the transport sector (Associação Nacional das Empresas de Transporte Urbano [NTU], 2020; De Vos, 2020; Lima et al., 2020). Demand decline is inevitable, with a large number of people working remotely and most leisure activities cancelled. Obviously, this is only a temporary situation, and participation in out-of-home activities and travel demand is expected to increase when circulation restrictions are lifted. It is expected that this is only a temporary situation and that the return to out-of-home activities will result in increased travel demand when travel restrictions are lifted. However, it is not known how long these measures will last and whether subsequent waves of contagion will come (De Vos, 2020).

The fear of social contact may still occur when the rules of social distancing are no longer in force (De Vos, 2020). Since public transport is considered a breeding ground for the virus, where it is difficult to avoid contact with other passengers, individuals may avoid using it (Troko et al., 2011; UITP, 2020). People with access to a car may drive more because they understand the car 'protects' them from other travellers (De Vos, 2020). Regular users of public transport may switch to taxi and app-based transport services, especially those without financial constraints (De Vos, 2020).

For short trips, the migration of users to active transport modes (biking and walking) to avoid social contact will also impact public transport demand (De Vos, 2020). Public authorities can temporarily stimulate walking and cycling by allocating underused space on the streets for cyclists and pedestrians (King \& Krizek, 2020). Cities around the world (Berlin, Vienna, Philadelphia, Vancouver, Bogotá, and Mexico City) are already transforming parking lanes into sidewalks and bicycle paths (Laker, 2020).

The decline in demand for public transport now and after social isolation eases, together with measures such as the intensification of hygiene, purchase of personal protective equipment and restrictions on vehicle capacity (increased supply disproportionately to usual demand) impose financial difficulties to operators (Badger, 2020; Foye, 2020; Lima et al., 2020; NTU, 2020). There is a 
trade-off in the operators and public authorities' decisions between limiting the financial impacts on the transport system by reducing supply and maintaining the operation of services with an adequate capacity to prevent the spread of the virus. However, even if there is the possibility to reduce expenses through operation adjustments, there is a high fixed cost to be covered by a revenue that may no longer exist. Where public transport has been interrupted by public authorities, fixed costs and lack of operating revenues will continue to pose financial difficulties on operators, who may not be able to keep operating after the end of social distancing. On average, in Brazil, $50 \%$ of the bus operators' expenses are labour payments (NTU, 2020).

Brazilian bus contracts are characterized mainly by the high risk allocated to operators, who generally assume the cost, operational, and revenue risks. However, in situations such as the COVID-19 crisis, it is implausible for operators to assume these risks individually. The new coronavirus pandemic is a force majeure, or fortuitous event, giving rise to a financial and economical balancing of contracts (Consultoria Jurídica junto ao Ministério da Infraestrutura [CONJUR], 2020). Furthermore, even systems subsidized by the government, where revenue risk is shared or allocated in the public entity, may face financial difficulties. Reduced economic activity due to COVID-19 may affect tax collection and, consequently, the transfer of subsidies to public transport.

The challenge of ensuring public transport service operation in the short term and restoring the financial balance of contracts in the medium and long term requires a prompt response from the public administration. The situation is particularly critical for smaller operators (Fletcher et al., 2014), who have limited liquidity to sustain losses during an extended period. According to NTU (2020), public transport companies are are becoming bankrupt in Brazil because of the crisis. In this scenario, firms with financial hardship may declare bankruptcy or be swallowed up by larger firms with significant financial capacity. If nothing is done, a greater concentration of the market is expected, which, from the point of view of competition and contestability, is undesirable (Gwilliam, 2008).

The solution to this entanglement is not yet ready and must be built up according to local specificities. The variability of the public transport regulators capacity may influence the solution design. While larger cities usually have independent regulatory bodies with sufficient financial and technical resources, other cities do not have a specialized body, and regulation occurs by contract. In a context of information asymmetry and with the threat of regulatory capture (Rolim, Brasileiro, \& Santos, 2010), companies with greater market power may use their position to gain advantages during financial and economical balancing negotiations. Alternatively, in an environment of low regulatory stability, companies are subject to provide a minimum service during the crisis, expecting to be rewarded by a future financial and economical balancing process. However, due to the inertia (or non-existence) of the regulator, this process may not occur in a reasonable and fair period to restore the financial health of companies.

Given the impacts caused by the COVID-19 pandemic on the operation of urban public bus services, this paper aims to provide guidelines for the renegotiation of bus contracts to guarantee the public interest and the fair financial and economical balancing of these services. The remainder of the article is organized in the following way. The next section presents the impacts of COVID-19 on the public bus transportation sector in Brazil and the actions taken by the public administration 
to minimize the harm. The third section briefly characterizes the Brazilian bus sector. Section four discusses the contracts' incompleteness and makes a case for financial and economical balancing in Brazilian bus contracts. Finally, section five recommends strategic actions for the balancing of contracts and presents the conclusions of the work.

\section{IMPACTS AND ACTIONS IN RESPONSE TO COVID-19 IN THE BRAZILIAN PUBLIC BUS TRANS- PORT SECTOR}

The main impact of COVID-19 on the public bus transportation sector derives from the voluntary or mandatory social isolation measures adopted by Brazilian cities and states. Unlike other public services, such as electric power, which had a 14\% drop in demand (Câmara de Comercialização de Energia Elétrica [CCEE], 2020), the patronage of urban bus services fell from 65 to $80 \%$ (Figure 1) (Lima et al., 2020; Moovit, 2020; NTU, 2020).

\section{FIGURE 1 PATRONAGE DECLINE IN PUBLIC TRANSPORT SYSTEMS BY BUS IN BRAZIL}

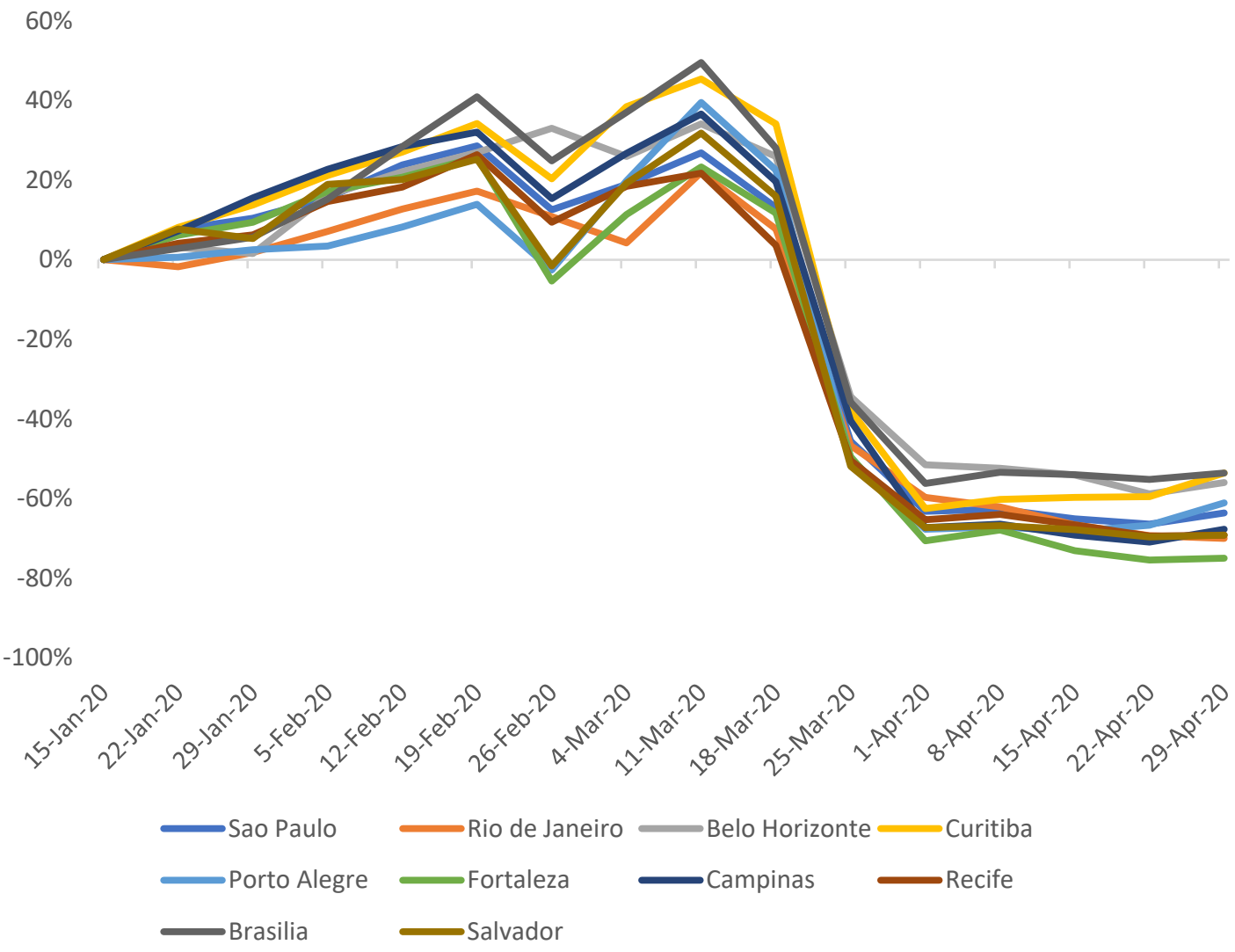

Source: Moovit (2020) 
Faced with the patronage reduction, some operators, with the transport authority's permission, have reduced the fleet and the frequency of the service. Despite the authorization to adapt the supply, some municipalities issued decrees limiting the vehicles' occupancy to prevent the spread of the disease (e.g., Porto Alegre/RS). Adjusting the supply is essential not only to limit the financial harm but also to ensure that workers remain healthy and safe, and to keep the system running (Goldbaum, 2020). According to NTU (2020), the average reduction in the supply of services in the country was $25 \%$. There was a total shutdown of bus services in 180 municipalities (NTU, 2020), 175 of them in the state of Santa Catarina. The decrees concerning some of the measures cited are summarized in Box 1.

\section{BOX 1}

\section{PUBLIC AUTHORITIES' ACTS THAT INFLUENCE THE LEVEL OF SERVICE OF PUBLIC BUS TRANSPORT}

\begin{tabular}{|c|c|c|}
\hline Measure & Municipality/State & Act \\
\hline \multirow[t]{5}{*}{ Matching supply and demand } & São Paulo & Decree n. 59.283 of March 16, 2020 \\
\hline & São Paulo & External Communication ARTESP DPL n. 03/2020 \\
\hline & Espírito Santo & Supplementary regulation CETURB/ES n. 003/2020 \\
\hline & Espírito Santo & Supplementary regulation CETURB/ES n. 004/2020 \\
\hline & Teresina & Decree n. 19.548 of March 29, 2020 \\
\hline \multirow[t]{6}{*}{ Reduction in occupancy } & Porto Alegre & Decree n. 20.549 of April 22, 2020 \\
\hline & Rio Grande do Sul & Decree n. 55.154 of April 01, 2020 \\
\hline & Rondônia & Decree n. 24.979 of April 26, 2020 \\
\hline & Goiânia & Decree n. 951 of April 28, 2020 \\
\hline & Campo Grande & Decree n. 14.271 of April 29, 2020 \\
\hline & Palmas & Decree n. 1.863 of March 22, 2020 \\
\hline \multirow{5}{*}{$\begin{array}{l}\text { Restriction of inter-municipal or } \\
\text { metropolitan bus service }\end{array}$} & Rio de Janeiro & Ordinance Detro/Pres n. 1.523 of April 06, 2020 \\
\hline & Rio de Janeiro & $\begin{array}{l}\text { Joint Resolution SEDEERI/SETRANS n.11 of April 07, } \\
2020\end{array}$ \\
\hline & Belo Horizonte & Decree n. 17.326 of April 6, 2020 \\
\hline & Pernambuco & Decree n. 48.834 of March 20, 2020 \\
\hline & Acre & Decree n. 5.812 of April 17, 2020 \\
\hline \multirow[t]{3}{*}{ Public transport interruption } & João Pessoa & Decree n. 9.472 of April 17, 2020 \\
\hline & Florianópolis & Decree n. 21.357 of March 19, 2020 \\
\hline & Florianópolis & Ordinance n. 008/Smpu/Gab/2020 \\
\hline \multirow{2}{*}{$\begin{array}{l}\text { Interruption of inter-municipal or } \\
\text { metropolitan bus service }\end{array}$} & Rio de Janeiro & Decree n. 47.052 of April 29, 2020 \\
\hline & Bahia & Decree n. 19.635 of April 14, 2020 \\
\hline
\end{tabular}

Source: Elaborated by the authors. 
Other impacts of COVID-19 in the sector are company bankruptcies (Guarulhos/SP), mass dismissals, suspension of labour contracts (Florianópolis/SC, Campina Grande/PB, Rio de Janeiro/RJ, Itabuna/BA), and reduction of working hours (São Paulo/SP). Some municipalities are implementing wage instalment strategies (Belo Horizonte/MG, Goiânia/GO), and work schedule alternations (Manaus/AM, Americana/SP). According to the NTU (2020), if the average reduction in the supply of around $25 \%$ is maintained, around 62 thousand drivers, 50 thousand collectors, and another 12 thousand professionals from bus companies will be dismissed. The public bus transportation sector in Brazil, directly and indirectly, employs about 1.8 million people and has an annual turnover of about R\$ 42.1 billion (NTU, 2020).

Many of the labour-related actions taken were based on Provisional Measure (MP) 936 (2020). This MP aims to preserve employment and income, ensure the continuity of business and labour activities, and reduce the social impact of COVID-19. Among the foreseen measures is the payment of an emergency income benefit in case of a reduction of working hours and wages or temporary suspension of the employment contract. In cases of working hours and wage reductions, the value of the hourly wage must be preserved, and the reduction cannot differ from 25\%, 50\%, or 75\%. Furthermore, the suspension of the employment contract is limited to a maximum period of 60 days, during which the employee continues to receive the benefits granted by the employer. MP 936 applies to employees with a monthly salary equal to or lower than $\mathrm{R} \$ 3,135.00$, or those with a university degree and who receive a monthly salary equal to or higher than twice the maximum limit of benefits under the General Social Security Policy.

The operators may adjust the salaries of employees, as supported by Article 503 of Law No. 5,452 (1943). According to the article, in case of force majeure or proven losses, the general reduction of salaries is legal. The reduction may not exceed $25 \%$, respecting the minimum wage of the region.

The total estimated loss of reduced demand caused by the new coronavirus pandemic was $\mathrm{R} \$ 2.5$ billion (NTU, 2020) in the first month of isolation. This is the amount one of the proposals demands monthly to overcome the crisis. The National Association of Urban Transport Companies (NTU), together with the National Forum of Secretaries and Public Officers of Urban Mobility and the National Association of Public Transport (ANTP), and supported by the National Front of Mayors, proposed the creation of the Social Transport Program to the Ministry of Economy. The program includes allocating R $\$ 2.5$ billion per month from the federal government for the purchase of fare credits while the COVID-19 pandemic lasts.

The Social Transport Program's central idea is an agreement by the three government levels (federal, state, and municipal) of a minimum level of service provided during the pandemic. Such minimum level would be established in percentage and the limit of the reduction of the number of buses in operation as foreseen in the respective contracts between the local granting power and the respective transport concessionaires (NTU, 2020). The fare credits would be used in the Federal Government's social assistance programs and distributed monthly for a period of 12 months from the end of the agreement period. Another proposal made by the NTU is a $50 \%$ reduction in the price of diesel oil charged by Petrobras (NTU, 2020). 
There are also municipal initiatives to ensure the operation of public transport services. In the city of Belo Horizonte, the municipality makes weekly payments of around R $\$ 3.5$ million to operators advancing transportation vouchers for its employees. In Curitiba, there is a law proposal instituting an emergency regime for the operation and funding of public transportation. The law proposes payments to the operators for exclusively administrative and labourer costs, employees' healthcare plans, life insurance, staple food, and taxes. The idea is that payments guarantee the maintenance of essential services at minimum operational levels.

While initiatives, such as those highlighted, are essential for the maintenance of the public transport system at the moment, it is crucial to consider the medium and long-term effects that the granting of such subsidies will have on the public budget. Due to the pandemic, public administration actions that previously would have needed months to be implemented are often implemented in a matter of days (Fletcher et al., 2014). However, because of the speed of decision making, the commitment of these public resources is probably not foreseen in the Annual Budget Law. In turn, this may imply the reallocation of resources and the failure to address some other equally important agenda.

\section{URBAN BUS SERVICES IN BRAZIL}

Bus systems in Brazil were effectively consolidated in the 1960s and 1970s when services emerged without any intervention from public authorities in planning routes and timetables. Therefore, it was up to the operators to understand the demands of the population and create more profitable routes. While tram networks were set aside, municipalities began to create public transportation companies to impose regulatory policies on bus operators, which were forced to merge among them and standardize their vehicles. This situation led to the beginning of modern and formal bus companies (Almeida Motta, Da Silva, \& De Sequeira Santos, 2013).

Currently, the Brazilian Constitution establishes in Article No. 175 that all public services must be provided publicly or privately through a bidding process, which will result in a contract. The private companies' concession or permission to provide public services is subject to competitive bidding criteria. According to Law 8.987/1995, the award criteria are the lowest tariff price of the service; the highest monetary offer to the government to operate the services; the best technical bid, with the price defined in the bid terms; or a combination of these criteria (Gomide \& Carvalho, 2016).

Unfortunately, according to Rolim et al. (2010), local bus industries have been structurally concentrated and presents strong evidence of regulatory capture. This process dates back to the 1950s and 1960s when fleet owners, which had precarious licenses, were expanding their operations, incorporating competitors, and increasing their territory, and market power. In many cases, they verticalized their activities by acting in the financing, commercialization, and maintenance of vehicles (Mesentier, Malburg, Souza, Amicci, \& Santos, 2018).

Rolim et al. (2010) argue that most existing contracts are not the result of public tenders and that the right to operate was automatically renewed, without being submitted to competitive processes. Thus, competition for the market has been the exception and not the rule. According to Gómez-Lobo and Briones (2014), in developing countries, institutions often lack human resources, the enforcement capacity is low, the legal systems are slow, the access to financial markets is limited, and the budget for 
investments and subsidies is scarce. Laffont (2005) adds that developing countries often suffer from a lack of up-to-date technology, poorly developed accounting and auditing systems due to an absence of adequate training programs for government employees, and corruption which is often present in relations between the private and public sectors.

\section{CONTRACT INCOMPLETENESS AND THE NEED FOR RENEGOTIATION}

Contracts are naturally incomplete, presenting vague requirements and omissions on many key aspects (Tirole, 1999). It is impossible, or sometimes very costly, to incorporate all contingencies and procedures to follow in each possible scenario. This shortcoming, therefore, is one of the main arguments in favour of contracts, which is incomplete by nature and with greater flexibility (Domingues \& Zlatkovic, 2015). Many problems that arise in public tenders, for example, are related to the need for ex-post adaptations to unforeseen contingencies in contracts (De Brux \& Desrieux, 2014).

In the urban bus market, concession contracts are mostly categorized into three groups (Cambini \& Filippini, 2003; Roy \& Yvrande-Billon, 2007; van de Velde, Beck, van Elburg, \& Terschüren, 2008; Organisation for Economic Cooperation and Development [OECD], 2013). In cost-plus contracts (also called management contracts), the operator is paid for all its previously permitted expenses, plus an additional fee to ensure a fair and reasonable profit. In this type of contract, both production (operation) and revenue risk are borne by the authority. In gross-cost contracts, companies compete to receive a specific amount to cover their costs (including some level of profit). At the same time, local authorities keep tariff revenues and bear the revenue risk. In addition to reducing the risk faced by the winning operator, such contracts also have the advantage of reducing the information asymmetry about the revenue level between new entrants and incumbents.

Net-cost contracts, formerly called full risk contracts, are those in which the operator bears all operating risks (costs and revenues). In this arrangement, the payment represents the difference between expected revenues and production costs. At the end of the accounting period, if the actual difference between the operating costs and the revenue does not correspond to the forecasted deficit, the operator assumes the loss. In the case of many Brazilian state capitals, operations gave a great magnitude and profit potential. Normally, a monetary payment by the winning operator to the transport authority for the exclusive right is a way to reduce the profit to a reasonable value and guarantee public interest.

The pandemic caused by COVID-19 can be considered a case of force majeure in bus contracts (CONJUR, 2020). It would have been impossible to predict this event at the time of the development of the bidding processes. Bus contracts in Brazilian cities, both net-cost and gross-cost, were not written with a consideration of operation adjustment measures due to pandemic events. As previously mentioned, the COVID-19 pandemic directly affects the public transport operation, causing supply disruptions and, mainly, affecting operators' revenues. In order to maintain operations, even if reduced, to ensure the liquidity of the companies, and keep jobs, the public authorities and operators must negotiate an economic and financial balancing of contracts and reach a joint agreement quickly.

As established in Subsection XXI of Article 37 of the Federal Constitution (1988), the financial and economical balance of the contract aims to maintain the 'effective conditions of the proposal'. As a result, the contract's original financial and economical equation is associated with the circumstances 
present at the time of the bid submission by the winning bidder. Secondly, there must be some supervening event to the proposal that justifies the need for balancing. Concerning the breaking of the financial and economical equation, Justen(2003, p. 390) states:

"The breakdown of the economic and financial equation can occur at any time and will be configured whenever some kind of extraordinary, unpredictable, or incalculable supervening event occurs, which amplifies the burdens or reduces the advantages originally assumed by the party."

Enterprise failure harms not only the concessionaire or tenant, but also the public service users. Therefore, there is a public interest in the stability of public service concession contracts (CONJUR, 2020). Though, in the current scenario where there are growing political concerns about collusion and corruption, all ex-post negotiations must be supported by transparent processes based on measurable metrics associated with public awareness and disclosure (Merkert, Preston, Melkersson, \& Link, 2018).

Considering the incompleteness of bus contracts, the severity of the situation caused by COVID-19, and the fear of regulatory collusion and capture, any measure adopted to address the situation must be open and transparent. The publicity of acts and financial resources of public administration and utilities allows citizens to identify fraud and corruption acts that could harm economic efficiency and social welfare. Because of the information asymmetry risk, it is also essential for the regulator to critically scrutinize accountability and transactions in order to have a greater ability to gauge the actual unbalances in the financial situation of companies.

\section{RECOMMENDATIONS AND CONCLUSIONS}

The social distancing measures imposed to limit the COVID-19 spread cannot be seen as a suspension of public transport services. Public transportation plays a crucial role in providing access for people seeking medical assistance. Besides, there is a range of professionals who rely solely on public transport services to commute. Nonetheless, the maintenance of public transport during a crisis faces challenges.

Since most bus contracts in Brazil are characterized by the allocation of demand risk on operators, public transport systems may suffer disproportionate effects due to the pandemic. The drop in demand, the intensification of cleaning procedures, the acquisition of personal protective equipment, and restrictions on vehicle occupancy during social isolation, reduce revenues and impose extra costs on operators. In cities where the public transport system has been shut down, labour fixed costs still need to be covered by an operating revenue that no longer exists. Even in subsidized transport systems where revenue risk is shared with the government, the economic slowdown can reduce the municipalities' revenues and, consequently, affect the transfer of subsidies to operators. Furthermore, after the loosening of social isolation, public transport patronage may change, resulting in a ridership lower than usual. All these factors threaten public transport's financial viability. Although the supply adjustment is a measure capable of attenuating the financial deficit of operators, there is a high fixed cost that needs to be covered and amortized.

The consequences of the COVID-19 crisis are already distinguishable in public transportation systems throughout the country. Verified impacts include company bankruptcies, mass dismissals, suspension of labour contracts, and working hour reductions. The situation is even more critical for 
smaller companies with little liquidity to sustain losses for an extended period. The bankruptcy of small companies also has a second-order effect, such as the market concentration and the consequent undermining of market competition and contestability.

Although the demand risk is allocated to operators in many of the contracts, it is not plausible that companies bear the losses (revenues shortfall) alone. In general, contracts are incomplete, and events such as the COVID-19 pandemic probably would be impossible to predict independently of the contract type (net-cost or gross-cost). Moreover, even if the pandemic could have been predicted with a high degree of reliability, the allocation of risk would still be hampered by the absence of adequate instruments. Insurance companies, for example, have not covered the impacts of pandemics yet. Such products, if indeed developed, would potentially be very costly for protection buyers.

Therefore, the new coronavirus crisis is a force majeure event, justifying a balancing of the financial-economic situation agreed on in contracts between operators and public authorities. There is a public interest in the stability of bus contracts. Since it is a public and essential service, the bankruptcy of transport companies harms not only the equity/capital owners but also the users of the service. Moreover, the continuity of services is critical to catalyse economic growth when the pandemic ends (Foye, 2020).

In order to keep the operations running, guarantee liquidity, and keep the bus companies' contracts, a prompt response is required from public administration. However, some regulatory characteristics and variables of the sector may hinder the design of an adequate solution now.

Due to the variability of regulatory capacity among cities in the country, the risk of regulatory capture is high, especially in smaller cities without regulatory entities and/or with insufficient and/or poorly qualified technical staff. The context of information asymmetry, weak enforcement capacity, and low regulatory certainty increases the risks of large companies using their market power to gain advantages in the financial-economic balancing processes. On the other hand, the low technical capacity, inertia, or even non-existence of regulatory bodies, alongside low regulatory certainty, can harm operators that have maintained the operations with a future financial balancing expectation. Thus, the transparency of the financial acts and resources of public authorities and regulated companies is fundamental at this time to prevent fraud and corruption that may harm economic efficiency and social welfare.

Given the scenario and the urgent need of contract financial balance, we recommend some actions/strategies:

1. The operators' accountability shall be detailed, presenting information on all the labour worked in operation and those employees who have been dismissed or had their contracts suspended. Additionally, companies shall disclose in detail all the services provided (routes and timetables), total kilometres travelled, and the costs involved.

2. In cases that a financial rescue occurred, companies must present all emergency resources provided by any sphere of government, detailing the amount, the form (loans, lost fund, etc.) and the origin of the resources.

3. The transport authority and/or regulatory entity shall require a financial report (cash flow, internal rate of return, etc.), proving the financial impact on the companies. 
4. Transparency should be the cornerstone of renegotiation processes. Therefore, we recommend the disclosure of all data, reports, processes, and decisions on an open website for media and public scrutiny.

5. In the absence of technical resources, municipalities can hire outside consultants (private consulting firms, specialized public bodies, higher education institutions, and mediation and arbitration chambers etc.) to mediate the negotiation if necessary.

6. In emergency cases, the municipality should provide the necessary resources for operators to continue the service and then renegotiate a tariff adjustment or other form of balancing the budget if overcompensation occurs. An alternative for municipalities with budgetary hardship would be to seek financing from public banks such as the Brazilian National Bank of Development (BNDES) and Caixa Econômica Federal. Recently BNDES announced financial aids to the aviation and electricity sectors, and there are aid negotiations for the urban mobility sector.

7. In cases where the demand level remains lower than expected after the loosening of social isolation measures, operators and regulators should consider reorganizing services to ensure adequate service provision and financial viability.

Finally, it is important to stress that decisions to guarantee the bus service operation must be taken quickly but cautiously. In order to overcome the uncertainties and consequences caused by the pandemic, it is essential to create relationships of trust and support between the private sector (operators) and public authorities. Regardless of the individual solutions adopted by municipalities, transparency must be the cornerstone for decision-making.

This crisis and its associated mitigation actions constitute a unique opportunity for the urban transport sector to adopt corporate governance practices. These practices are already prevalent in other regulated industries and can contribute to increase social participation and transparency and improve the regulatory process that are essential even in regular times. 


\section{REFERENCES}

Almeida Motta, R., Silva, P. C. M., \& Sequeira Santos, M. P. (2013). Crisis of public transport by bus in developing countries: a case study from Brazil. International Journal of Sustainable Development and Planning, 8(3), 348-361. Retrieved from https://doi. org/10.2495/SDP-V8-N3-348-361

Agência de Transporte do Estado de São Paulo. Comunicado Externo ARTESP DPL n. 3, de 2020. (2020). São Paulo, SP: Author. Retrieved from http://www.artesp.sp.gov.br/Shared $\% 20$ Documents/TransporteColetivo/Comunicados/ COMUNICADO-EXTERNO-DPL-03-2020.pdf

Associação Nacional das Empresas de Transporte Urbano. (2020, April). Covid-19 e o Transporte Público por Ônibus: Impactos no Setor e Ações Realizadas. Brasília, DF: Author. Retrieved from https://www.ntu.org.br/novo/upload/Publicacao/ Pub637231535674949776.pdf

Badger, E. (2020, April 09). Transit Has Been Battered by Coronavirus. What's Ahead May Be Worse. The New York Times. Retrieved from https://www. nytimes.com/2020/04/09/upshot/transit-batteredby-coronavirus.html? searchResultPosition $=2$

Câmara de Comercialização de Energia Elétrica. (2020, April). Acompanhamento do Consumo em Função da COVID-19. São Paulo, SP: Author. Retrieved from https://www.ccee.org.br/ccee/ documentos/CCEE_654419

Cambini, C., \& Filippini, M. (2003). Competitive tendering and optimal size in the regional bus transportation industry: an example from Italy. Annals of Public and Cooperative Economics, 74(1), 163-182.

Constitution of the Federative Republic of Brazil, 1988. (1988). Brasília, DF. Retrieved from http://www. planalto.gov.br/ccivil_03/constituicao/constituicao. htm

Consultoria Jurídica junto ao Ministério da Infraestrutura. (2020). Parecern. 261/2020/CONJURMINFRA/CGU/AGU. Consulta em tese. Covid-19. Requilíbrio de contratos de concessão. Força Maior. Consultoria Jurídica Junto Ao Ministério da Infraestrutura Gabinete da Consultoria Jurídica. Brasília: Felipe Nogueira Fernandes. Retrieved from: https://sapiens.agu.gov.br/documento/406894540
De Brux, J., \& Desrieux, C. (2014). To allot or not to allot public services? An incomplete contract approach. European Journal of Law and Economics, 37(3), 455-476. Retrieved from https:// doi.org/10.1007/s10657-012-9349-9

Decree $n$. 951, of april 28, 2020. (2020). Dispõe sobre medidas complementares de enfrentamento da crise provocada pela pandemia causada pelo novo coronavírus (COVID-19) nos serviços de transporte público coletivo e recomenda horários de funcionamento de estabelecimentos industriais, comerciais e de serviços, no âmbito do Município de Goiânia. Goiânia, GO. Retrieved from https:// sagresonline.com.br/wp-content/uploads/2020/04/ decreto_n_951.pdf

Decree n. 1.863, of march 22nd, 2020. (2020). Altera o Decreto $\mathrm{n}^{\circ} 1.856$, de 14 de março de 2020, que declara situação de emergência em saúde pública no município de Palmas e dispõe sobre medidas de enfrentamento da pandemia provocada pelo coronavírus (COVID-19), nas partes que especifica. Palmas, TO. Retrieved from http://diariooficial.palmas.to.gov.br/media/ diario/2454-22-3-2020-22-18-59.pdf

Decree n. 5.812, of april 17, 2020. (2020). Reitera e ratifica o reconhecimento do estado de calamidade pública e a declaração de situação de emergência em saúde, altera dispositivos e prorroga prazos do Decreto $n^{\circ} 5.496$, de 20 de março de 2020, que estabelece novas medidas para enfrentamento da emergência de saúde pública decorrente da doença COVID-19, causada pelo coronavírus SARS-CoV-2. Rio Branco, AC. Retrieved from http://diario.ac.gov.br/download. php?arquivo=KEQxQHI3IyEpRE8xNTg3MTczM DU3MzM3OC5wZGY=

Decree n. 9.472, of april 17, 2020. (2020). Prorroga o prazo de vigência de medidas temporárias ao enfrentamento da emergência de saúde pública de importância internacional decorrente do novo coronavírus, vetor da COVID-19, e dá outras providências. João Pessoa, PB. Retrieved from http:// www.joaopessoa.pb.gov.br/portal/wp-content/ uploads/2020/04/2020_Ed_Especial-17_04.pdf

Decree n. 14.271, of april 29, 2020. (2020). Acrescenta dispositivos ao Decreto n. 14.232, de 3 de abril de 2020, que "Estabelece medidas de contenção da propagação de contágio do COVID-19 para as atividades e a prestação dos serviços relativos 
ao Sistema Municipal de Mobilidade Urbana", e dá outras providências. Campo Grande, MS. Retrieved from http://portal.capital.ms.gov.br/egov/ downloadFile.php?id=8042\&fileField=arquivo_dia ofi\&table=diario_oficial\&key=id_dia_ofi\&sigla $\mathrm{sec}=$ diogrande

Decree n. 17.326, of april 06, 2020. (2020). Determina a proibição da circulação no território do Município de Belo Horizonte de transporte público coletivo oriundo de municípios queinterromperem as medidas de isolamento social. Belo Horizonte, MG. Retrieved from http://portal6.pbh.gov.br/dom/iniciaEdicao. do? method=DetalheArtigo \&pk=1227679

Decree n. 19.548, of March 29, 2020. (2020). Dispõe sobre o funcionamento das atividades de indústria, comércio, logística e sociais, para o atendimento mínimo às demandas da população de Teresina e do Poder Público, na vigência do "estado de calamidade pública", decorrente do novo coronavírus (COVID-19), no Município de Teresina, e dá outras providências. Teresina, PI. Retrieved from http:// dom.pmt.pi.gov.br/admin/upload/DOM273930032020-ASSINADO.pdf

Decree n. 19.635, of april 14, 2020. (2020). Altera o Decreto ${ }^{\circ} 19.586$, de 27 de março de 2020, na forma que indica, e dá outras providências. Salvador, BA. Retrieved from http://diarios.egba.ba.gov.br/html/ DO15/DO_frm0.html

Decree n. 20.549, of april 22, 2020. (2020). Altera os capita do art. $8^{\circ}$, do art. 10 e do art. 30 e inclui o parágrafo único no art. 10, todos do Decreto $\mathrm{n}^{\circ} 20.534$, de 31 de março de 2020, que decreta o estado de calamidade pública em razão da pandemia de importância internacional decorrente do novo Coronavírus (COVID-19) e dá outras providências. Porto Alegre, RS. Retrieved from http://dopaonlineupload.procempa.com.br/ dopaonlineupload/3340_ce_288405_1.pdf

Decree n. 21.357, of March 19, 2020. (2020). Proíbe o acesso à orla das praias, proíbe o tráfego de veículos de transporte coletivo e turístico de pessoas e dá outras providências. Florianópolis, SC. Retrieved from http://www.pmf.sc.gov. br/arquivos/diario/pdf/19_03_2020_18.24.54. c52850576e811b4883b2583a2a489f06.pdf

Decree n. 24.979, of april 26, 2020. (2020). Dispõe sobre o Estado de Calamidade Pública, regulamenta quarentena e restrição de serviços e atividades em todo o território do Estado de Rondônia e revoga o Decreto $^{\circ} 24.919$, de 5 de abril de 2020. Porto Velho, RO. Retrieved from http://www.diof.ro.gov.br/data/ uploads/2020/04/DOE-27.04.2020.pdf

Decree n. 47.052, of april 29, 2020. (2020). Dispõe sobre as medidas para enfrentamento da propagação decorrente do novo coronavírus (COVID-19), em decorrência da situação de emergência em saúde e dá outras providências. Rio de Janeiro, RJ. Retrieved from http://www.ioerj.com.br/ portal/modules/conteudoonline/mostra_edicao. php? session $=$ VWxWU1FrNXJSWGRSVkdO MF QxUld Raz Fw T URCU 1 J H c z B UR I Z K Z U U w d 1 N Y Uk 9 W R 3 N 6 V D B S U m QxRlVVa1ZQVkdjMA= = \&p $=M g==\& \mathrm{tb}=$ NDcuMDUyJiMwMTM7

Decree n. 48.834, of March 20, 2020. (2020). Define no âmbito socioeconômico medidas restritivas temporárias adicionais para enfrentamento da emergência de saúde pública de importância internacional decorrente do coronavírus. Recife, PE. Retrieved from https:// diariooficial.cepe.com.br/diariooficialweb/\#/ visualizar-jornal? dataPublicacao $=21-03$ 2020\&diario $=\mathrm{MQ} \% 3 \mathrm{D} \% 3 \mathrm{D}$

Decree n. 55.154, of april 1, 2020. (2020). Reitera a declaração de estado de calamidade pública em todo o território do Estado do Rio Grande do Sul para fins de prevenção e de enfrentamento à epidemia causada pelo COVID-19 (novo Coronavírus), e dá outras providências. Porto Alegre, RS. Retrieved from https://educacao.rs.gov.br/upload/ arquivos/202004/01154835-decreto-calamidadepublica-1.pdf

Decree n. 59.283, of March 16, 2020. (2020). Declara situação de emergência no Município de São Paulo e define outras medidas para o enfrentamento da pandemia decorrente do coronavírus. São Paulo, SP. Retrieved from http://legislacao.prefeitura.sp.gov.br/ leis/decreto-59283-de-16-de-marco-de-2020 .

De Vos, J. (2020, April 24). The effect of COVID-19 and subsequent social distancing on travel behavior. Transportation Research Interdisciplinary Perspectives, 5, 100121. Retrieved from https://doi.org/10.1016/j. trip.2020.100121

Domingues, S., \& Zlatkovic, D. (2015). Renegotiating ppp contracts: reinforcing the ' $p$ 'in partnership. 
Transport Reviews, 35(2), 204-225. Retrieved from https://doi.org/10.1080/01441647.2014.992495

External Communication ARTESP DPL n. 03, 2020. (2020). São Paulo, SP. Retrieved from http://www.artesp.sp.gov.br/Shared $\% 20$ Documents/TransporteColetivo/Comunicados/ COMUNICADO-EXTERNO-DPL-03-2020.pdf

Fletcher, K., Amarakoon, S., Haskell, J., Penn, P., Wilmoth, M., Matherly, D., \& Langdon, N. (2014). A guide for public transportation pandemic planning and response. Washington, DC: The National Academies Press. Retrieved from https://doi. org/10.17226/22414

Foye, P. J. (2020, March 24). The M.T.A. Needs Help. Now. The New York Times. Retrieved from https:// www.nytimes.com/2020/03/24/opinion/mta-newyork-transit.html?searchResultPosition=7

Goldbaum, C. (2020, March 24). Subway service is cut by a quarter because of coronavirus. The New York Times. Retrieved from https://www.nytimes. com/2020/03/24/nyregion/coronavirus-nyc-mtacuts-.html? searchResultPosition $=6$

Gómez-Lobo, A., \& Briones, J. (2014). Incentives in bus concession contracts: a review of several experiences in Latin America. Transport Reviews, 34(2), 246-265. Retrieved from https://doi.org/10.1 080/01441647.2014.895451

Gomide, A. A., \& Carvalho, C. H. R. de. (2016, March). Transformações e Tendências Recentes na Regulação dos Serviços de Ônibus Urbano no Brasil (Texto para Discussão, n. 2197). Rio de Janeiro, RJ: Instituto de Pesquisa Econômica Aplicada. Retrieved from https://www.ipea.gov.br/portal/images/stories/ PDFs/chamadas_publicas/promob/2016/td_2187. pdf

Gwilliam, K. (2008). Bus transport: is there a regulatory cycle? Transportation Research Part A: Policy and Practice, 42(9), 1183-1194. Retrieved from https://doi.org/10.1016/j.tra.2008.05.001

Joint Resolution SEDEERI/SETRANS n.11 of April 07, 2020. (2020). Disciplina as restrições de circulação de pessoas no transporte intermunicipal de passageiros no estado do Rio de Janeiro, e dá outras providências. Rio de Janeiro, RJ. Retrieved from http://www.ioerj.com.br/portal/ modules/conteudoonline/mostra_edicao. php? session $=$ VVdwVmVVNVZVa1pSVkZGM FRtcEZlazFwTURCTlJFa3dURlZLUms5RW EzUlJhMFV5VG10 Uk1GSIVSVFZQUlZwQw= $=\& \mathrm{p}=\mathrm{OA}==\& \mathrm{tb}=\mathrm{cmVzb} 2 \times 1 \mathrm{w} 6 \mathrm{fD}$ o $28 \mathrm{gY} 29$ uanVudGEmIzAxMzs=

Justen, M., Filho. (2003). Teoria geral das concessões de serviço público. São Paulo, SP: Dialética..

King, D. A., \& Krizek, K. J. (2020). The power of reforming streets to boost access for human-scaled vehicles. Transportation Research Part D: Transport and Environment, 83, 102336. Retrieved from https:// doi.org/10.1016/j.trd.2020.102336

Laffont, J. J. (2005). Regulation and development. Cambridge, UK: Cambridge University Press. Retrieved from https://doi.org/10.1017/ CBO9781139163392

Laker, L. (2020, April 11). World cities turn their streets over to walkers and cyclists. The Guardian. Retrieved from https://www.theguardian.com/ world/2020/apr/11/world-cities-turn-their-streetsover-to-walkers-and-cyclists?CMP=share_btn_tw

Law n. 5.452, of May 1, 1943. (1943). Aprova a Consolidação das Leis do Trabalho. Rio de Janeiro. Retrieved from http://www.planalto.gov.br/ ccivil_03/decreto-lei/del5452.htm

Law n. 8.987, of february 13, 1995. (1995). Dispõe sobre o regime de concessão e permissão da prestação de serviços públicos previsto no art. 175 da Constituição Federal, e dá outras providências. Brasília, DF. Retrieved from: http://www.planalto. gov.br/ccivil_03/leis/18987cons.htm

Lima, G. C. L. S., Schechtman, R., Brizon, L. C., Figueiredo, Z. M. (2020, April). Transporte público e COVID-19. O que pode ser feito?. Rio de Janeiro, RJ. Centro de Estudos em Regulação e Infraestrutura da Fundação Getúlio Vargas (FGV CERI). Retrieved from https://ceri.fgv.br/ sites/default/files/publicacoes/2020-04/covid_e_ mobilidade_urbana_fgv_ceri.pdf

Merkert, R., Preston, J., Melkersson, M., \& Link, H. (2018). Workshop 2 report: Competitive tendering and other forms of contracting-out: Institutional design and performance measurement. Research in Transportation Economics, 69, 86-96. Retrieved from https://doi.org/10.1016/j.retrec.2018.08.002 
Mesentier, A. A. P. de, Malburg, C. H. R., Souza, F. de O., Amicci, A. G. N., \& Santos, R. T. dos. (2018). Panorama setorial 2015-2018: mobilidade urbana. Rio de Janeiro - RJ, Banco Nacional do Desenvolvimento (BNDES). Retrieved from https://web.bndes.gov.br/ bib/jspui/bitstream/1408/14960/1/Mobilidade\%20 urbana_P_BD.pdf

Metrô - SP. (2019, July). Pesquisa Origem Destino 2017. 50 Anos. A Mobilidade Urbana da Região Metropolitana de São Paulo em Detalhes. Relatório Síntese E-Book. São Paulo - SP, Companhia Do Metropolitano De São Paulo - Metrô. Retrieved from http://www.metro.sp.gov.br/pesquisa-od/arquivos/ Ebook\%20Pesquisa\%20OD\%202017_final_240719_ versao_4.pdf

Moovit. (2020). Impact of Coronavirus (COVID-19) on Public Transit usage. Retrieved from https:// moovitapp.com/insights/en/Moovit_Insights_ Public_Transit_Index-countries

Ordinance Detro/Pres n. 1.523 of April 06, 2020. (2020). Dispõe sobre alteração no inciso VIII, do Art. $4^{\circ}$ do Decreto No 47.006, de 27 de Março de 2020 em decorrência da emergência de saúde pública de importância internacional decorrente do coronavírus (COVID-19), e dá outras providências. Rio de Janeiro, RJ. Retrieved from http://www.ioerj.com. br/portal/modules/conteudoonline/mostra_edicao. php? session $=$ VVdwVmVVNVZVa1pSVkZGMFR t c E Z l a z F w T U R C T $1 \mathrm{JFa} 3 \mathrm{~d}$ U R 1 Z L U m s 5 R W E z U l J h M V 5 V G 10 U k 1 G S $1 \mathrm{~V} \mathrm{~S} \mathrm{~V} \mathrm{~F} \mathrm{Z} \mathrm{Q} \mathrm{U} 1 \mathrm{Z}$ w Q w $==\& \mathrm{p}=\mathrm{M} \mathrm{T}$

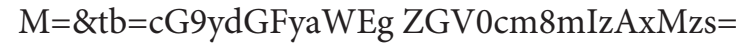

Ordinance n. 008/Smpu/Gab/2020. (2020). Torna sem efeito a portaria n. 07 de 03 abril de 2020 e altera e consolida as portarias $03,04,05$ e 06 publicadas entre os dias 19 de março de 2020 à 26 de março de 2020 que estabelecem medidas emergenciais no âmbito da secretaria municipal de mobilidade e planejamento urbano de Florianópolis - SMPU. Florianópolis, SC. Retrieved from http://www.pmf.sc.gov.br/arquivos/ diario/pdf/03_04_2020_19.44.18.1e5c7afb3244c38 f3996538251c95f12.pdf

Organisation for Economic Co-operation and Development - OECD. (2013, February). Methods for Allocating Contracts for the Provision of Regional and Local Transportation Services. Retrieved from http://www.oecd.org/daf/competition/
Pereira, R. H. M., Braga, C. K. V., Servo, L. M., Serra, B., Amaral, P. \& Gouveia, N. (2020, April). Nota Técnica 14. Mobilidade Urbana e o Acesso ao Sistema Único de Saúde para Casos Suspeitos e Graves de COVID-19 nas Vinte Maiores Cidades do Brasil. Dirur - Diretoria de Estudos e Políticas Regionais, Urbanas e Ambientais. Instituto de Pesquisa Econômica Aplicada. Brasília, Abril de 2020. Retrieved from https://www.ipea.gov.br/ portal/images/stories/PDFs/nota_tecnica/200408_ nota_tecnica_14_dirur.pdf

Provisional Measure n.936, of April 1, 2020. (2020). Institui o Programa Emergencial de Manutenção do Emprego e da Renda e dispõe sobre medidas trabalhistas complementares para enfrentamento do estado de calamidade pública reconhecido pelo Decreto Legislativo $n^{\circ}$ 6, de 20 de março de 2020, e da emergência de saúde pública de importância internacional decorrente do coronavírus (Covid-19), de que trata a Lei no 13.979, de 6 de fevereiro de 2020, e dá outras providências. Brasília, DF. Retrieved from http://www.planalto.gov.br/ccivil_03/_Ato20192022/2020/Mpv/mpv936.htm .

Rodrigues, J. M. (2016). Qual o estado da mobilidade urbana no Brasil? Mobilidade urbana no Brasil: desafios e alternativas. O estado de acessibilidade para portadores de deficiência nas cidades brasileiras. Rio de Janeiro - RJ, Heinrich-Böll-Stiftung. Retrieved from https://br.boell.org/sites/default/ files/mobilidade_urbana_boll_brasil_web_.pdf

Rolim, F., Brasileiro, A., \& Santos, E. (2010). Competition in Brazilian bus and coach servicesThe results of recent competitive tendering processes. Research in Transportation Economics, 29(1), 45-51.

Roy, W., \& Yvrande-Billon, A. (2007). Ownership, contractual practices and technical efficiency: The case of urban public transport in France. Journal of Transport Economics and Policy (JTEP), 41(2), 257-282.

Supplementary regulation CETURB/ES n. 003, 2020. (2020). Dispõe sobre medidas de caráter excepcional e temporário às empresas transportadoras que operam sob delegação do Estado do Espírito Santo, os Serviços Autorizados e Concessionados, no âmbito do Sistema de Transporte Rodoviário Intermunicipal de Passageiros do Estado do Espírito Santo - SITRIP/ ES, para enfrentamento da emergência de saúde pública decorrente do coronavírus (COVID-19). 
Vitória, ES. Retrieved from https://ceturb.es.gov. br/Media/ceturb/Legisla\%C3\%A7\%C3\%A3o/ Norma\%20Complementar\%20003-2020.pdf

Supplementary regulation CETURB/ES n. 004, 2020. (2020). Altera a Norma Complementar n $n^{\circ} 03 / 2020$, de 19 de março de 2020, e dá outras providências no âmbito do enfrentamento da emergência de saúde pública decorrente da infecção Humana pelo novo coronavirus (COVID-19). Vitória, ES. Retrieved from https://ceturb.es.gov.br/Media/ ceturb/Legisla\%C3\%A7\%C3\%A3o/Norma\%20 Complementar\%20004-2020.pdf

Tirole, J. (1999). Incomplete contracts: Where do we stand?. Econometrica, 67(4), 741-781.
Troko, J., Myles, P., Gibson, J., Hashim, A., Enstone, J., Kingdon, S., ... Van-Tam, J. N. (2011). Is public transport a risk factor for acute respiratory infection?. BMC infectious diseases, 11(1), 16.

Union Internationale des Transport Publics - UITP (2020, February). Management of COVID-19 Guidelines For Public Transport Operators. Retrieved from https://www.uitp.org/management-Covid-19guidelines-public-transport-operators

Van de Velde, D., Beck, A., Van Elburg, J., \& Terschüren, K. H. (2008). Contracting in urban public transport. Amsterdam: European Commission, 123. Retrieved from https://ec.europa.eu/transport/sites/ transport/files/themes/urban/studies/doc/2008_ contracting_urban_public_transport.pdf

\section{Gregório Costa Luz de Souza Lima}

https://orcid.org/0000-0002-1041-6179

Master's degree student in Transportation Engineering at the Federal University of Rio de Janeiro (PET/COPPE). E-mail: gregorioluz@pet.coppe.ufrj.br

\section{Gabriel Stumpf Duarte de Carvalho}

https://orcid.org/0000-0002-8333-7789

Researcher at Department of Civil Engineering, Architecture and Georesources (DECivil) of Instituto Superior Técnico de Lisboa (IST - Lisboa). E-mail: gabrielstumpf@tecnico.ulisboa.pt

\section{Miguel Zobaran Figueiredo}

https://orcid.org/0000-0001-8313-3834

Research assistant at the Center for Regulatory and Infrastructure Studies of Fundação Getulio Vargas (FGV CERI). E-mail: miguel.figueiredo@fgv.br 